\title{
AN EXPEDITIOUS ROUTE FOR THE SYNTHESIS OF THIADIAZOLO - PYRIMIDIN - 2- THIONES USING MICROWAVES
}

\author{
A.D. Mishra *
}

\begin{abstract}
A series of 1-(1,3,4-thiadiazolo)-2-thioxo-pyrimidines 4a-g are synthesized by the condensation of monosubsituted thioureas la-g, ethyl acetoacetate 2 and aryl aldehyde 3 in dry media using microwave irradiation. The reactions are completed in very short time with high yield. The use of inorganic solid supports has been proved as an alternative mean of synthetic media.
\end{abstract}

\section{INTRODUCTION}

Thiadiazolo-pyrimidin-2-thiones have been found pharmacologically important as antitumor, antiallergic, antiviral, antifungal, anti-inflammatory and antihypertensive agents (Deb and Kotha 2008, Douglas et. al. 2003, Gardisa et. al 1996). The wider therapeutic application of these compounds has drawn the concern to synthesize these novel compounds. Several conventional and nonconventional methods have been reported (Mishra and Damkar, 2006; Renhowe et. al., 1995; Bending et al., 1994) for the synthesis of thiadiazolo-pyrimidin-2thiones, which have many synthetic complications. The drawbacks of these methods have been overcomed by synthesizing the title compounds under microwave irradiation using solid supports (Kapple et. al., 1992). Microwave assisted organic synthesis proceeds with facile reactions to furnish good yield within very short time period (Kapple and Roschger, 1989). Further, this technique avoids the usage of excess organic solvents (Kidwai et. al., 2002). Solution phase (Verma, 1999) microwave reaction has some limitations of super heating of the solvent which may lead to explosion. So the solid supported (Caddick, 1995) dry media synthesis has been adopted as an efficient and eco friendly technique using microwave ovens conveniently (Banaerjee and Tyagi, 2009). These solid supports, viz. alumina, silica gel, montmorillonite, provide acidic, basic and neutral conditions and reduce the amount of toxic wastes and byproducts in chemical transformations.

\section{EXPERIMENTAL METHODS}

Microwave irradiations were carried out in Kenstar Microwave Oven, (2450 $\mathrm{MHz}$, and $800 \mathrm{~W})$. IR spectra $\left(\mathrm{v}, \mathrm{cm}^{-1}\right)$ were recorded on a Perkin-Elmer FTIR-1710 spectrophotometer using KBr-pellets; and ${ }^{1} \mathrm{H}$ NMR spectra on a FTNMR Hitachi-R$600(60 \mathrm{MHz})$ instrument using TMS as internal reference (chemical shifts in $\delta, \mathrm{ppm}$ ). Elemental analyses were performed by means of Heraeus CHN-Rapid Analyzer. Temperatures of reaction mixture were measured on AZ, Mini Gun type non-contact IR thermometer. All the melting points were determined on a Thomas Hoover melting point apparatus and are uncorrected. The purity of the compounds was checked on aluminum plates coated with silica gel (Merk).

\footnotetext{
* Associate Professor, P.N. Campus, Tribhuvan University, Pokhara, Nepal
} 
Scheme 1
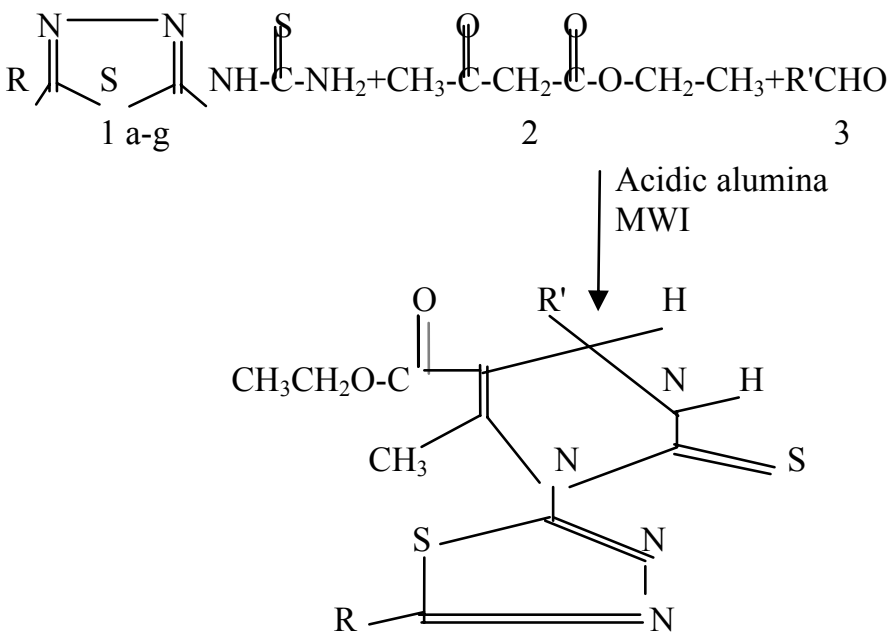

4a-g

R1=3-Nitrophenyl

$\mathrm{R}=$ (a) Phenyl $\quad$ (b) 3-Nicotinyl (c) 4-Nicotinyl (d) 2-Furyl

(e) 2-Thionyl (f) Heptyl (g) Nonyl

General procedure for the synthesis of $\mathrm{N}-(5$ - subsituted -1,3,4thiadiazolo) thioureas la-g:

These compounds were prepared according to literature method (Daneud et. al. 2002).

General procedure for the synthesis of 1-(5-subsitituted-1,3,4thiadiazolo)-6-methyl-4-substituted-2- thioxo-1,2,3,4-tetrahydropyrimidin-5 ethyl carboxylate 4a-g:

Conventional method (Method A): Equimolar amount ( 0.01 mole) of thioureas la-g, ethyl acetoacetate 2 and aldehyde 3 were dissolved in $20 \mathrm{ml}$ of EtOH. To this $1 \mathrm{ml}$ of conc. HCI was added. The resulting solution was refluxed for 3-4 hr. After the completion of reaction as checked by TLC, the refluxing mixture was cooled and poured into the crushed ice to obtain solid produce $4 \mathrm{a}-\mathrm{g}$. The product was filtered, washed with cold water and recrystallized from $\mathrm{MeOH}$.

Microwave method (Method B): 0.01 mole of thioureas la-g, ethyl acetoacetate 2 and aldehyde 3 were dissolved in $10 \mathrm{~mL}$ of EtOH and the resulting solution was adsorbed over $20 \mathrm{~g}$ of acidic alumina or montmorillonite $\mathrm{K} 10$ clay in a $100 \mathrm{~mL}$ beaker. The reaction mixture was dried in air and subjected to microwave irradiation for 7-8 min.

Reaction was monitored at an interval of 30 seconds using TLC. The product $4 \mathrm{a}-\mathrm{g}$ was extracted with $\mathrm{EtOH}(4 \mathrm{X} 10 \mathrm{~mL})$ and obtained in solid state after 
removing EtOH by distillation, under reduced pressure. The product was recrystallized from $\mathrm{MeOH}$.

\section{RESULTS}

Thioureas la-g were reacted with ethyl acetoacetate 2 and aldehyde 3 using acidic alumina as solid support under microwave irradiations to obtain substituted-2-thioxopyrimidines $4 \mathrm{a}-\mathrm{g}$ (Scheme 1). The reaction was completed in 7-8 $\mathrm{min}$. The same reaction took 3-4 $\mathrm{hr}$ for completion in conventional method. The yield in micro-wave irradiation method was found within the range of 72$87 \%$ and that in the conventional method 50-65\%. Particular physical characterization and the comparative studies of the synthesized compounds are given (Table 1). Use of montmorillonite K10 clay instead of acidic alumina reduced reaction time with high yield.

Table 1. Comparison of reaction time period and yields of products $4 \mathrm{a}-\mathrm{g}$ and their ${ }^{1} \mathrm{H}$ NMR spectra

\begin{tabular}{|c|c|c|c|c|c|c|c|}
\hline \multirow[b]{2}{*}{$\begin{array}{l}\overline{\tilde{E}} \\
\text { है }\end{array}$} & \multirow[b]{2}{*}{$\mathbf{R}$} & \multirow[b]{2}{*}{$\underset{{ }^{0} \mathbf{C}}{\mathbf{m} . \mathbf{p}}$} & \multicolumn{2}{|c|}{$\begin{array}{l}\text { Reaction } \\
\text { Time }\end{array}$} & \multicolumn{2}{|c|}{$\%$ Yield } & \multirow[t]{2}{*}{$\begin{array}{c}\text { 1H NMR }\left(\mathrm{CDC1}_{3}+\mathrm{DMSO}-\mathrm{d}_{6}\right)(\delta, \\
\mathrm{ppm})\end{array}$} \\
\hline & & & 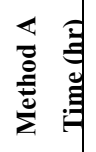 & 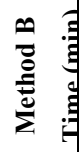 & 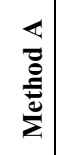 & 总 & \\
\hline $4 a$ & Phenyl & 157 & 4.0 & 8.0 & 55 & 75 & $\begin{array}{l}1.3\left(\mathrm{t}, 3 \mathrm{H}, \mathrm{OCH}_{2}-\mathrm{CH}_{3}\right), \\
2.4\left(\mathrm{~s}, 3 \mathrm{H}, \mathrm{CH}_{3}\right), \\
5.2(\mathrm{~d}, 1 \mathrm{H}, \mathrm{CH}), \\
4.0\left(\mathrm{q}, 2 \mathrm{H}, \mathrm{OCH}_{2}-\mathrm{CH}_{3}\right), \\
7.3-8.0(\mathrm{~m}, 9 \mathrm{H}, \mathrm{Ar}-\mathrm{NH}) \\
10.6(\mathrm{brs}, 1 \mathrm{H}, \mathrm{NH})\end{array}$ \\
\hline $4 b$ & 3-Nicotinly & 162 & 3.5 & 7.0 & 59 & 82 & $\begin{array}{l}1.3\left(\mathrm{t}, 3 \mathrm{H}, \mathrm{OCH}_{2}-\mathrm{CH}_{3}\right), \\
2.4\left(\mathrm{~s}, 3 \mathrm{H}, \mathrm{CH}_{3}\right), \\
5.2(\mathrm{~d}, 1 \mathrm{H}, \mathrm{CH}), \\
4.0\left(\mathrm{q}, 2 \mathrm{H}, \mathrm{OCH}_{2}-\mathrm{CH}_{3}\right), \\
7.4-8.5(\mathrm{~m}, 8 \mathrm{H}, \mathrm{Ar}-\mathrm{H}) \\
10.6(\mathrm{brs}, 1 \mathrm{H}, \mathrm{NH})\end{array}$ \\
\hline $4 c$ & 4-Nicotinyl & 174 & 3.5 & 7.5 & 57 & 80 & $\begin{array}{l}1.2\left(\mathrm{t}, 3 \mathrm{H}, \mathrm{OCH}_{2}-\mathrm{CH}_{3}\right), \\
2.3\left(\mathrm{~s}, 3 \mathrm{H}, \mathrm{CH}_{3}\right), \\
5.2(\mathrm{~d}, 1 \mathrm{H}, \mathrm{CH}), \\
4.1\left(\mathrm{q}, 2 \mathrm{H}, \mathrm{OCH}_{2}-\mathrm{CH}_{3}\right), \\
6.9-8.4(\mathrm{~m}, 8 \mathrm{H}, \mathrm{Ar}-\mathrm{H}) \\
10.7(\mathrm{brs}, 1 \mathrm{H}, \mathrm{NH})\end{array}$ \\
\hline
\end{tabular}




\begin{tabular}{|c|c|c|c|c|c|c|c|}
\hline $4 d$ & 2-Furyl & 148 & 3.0 & 7.5 & 63 & 85 & $\begin{array}{l}1.3\left(\mathrm{t}, 3 \mathrm{H}, \mathrm{OCH}_{2}-\mathrm{CH}_{3}\right), \\
2.4\left(\mathrm{~s}, 3 \mathrm{H}, \mathrm{CH}_{3}\right), \\
5.3(\mathrm{~d}, 1 \mathrm{H}, \mathrm{CH}), \\
4.0\left(\mathrm{q}, 2 \mathrm{H}, \mathrm{OCH}_{2}-\mathrm{CH}_{3}\right), \\
6.3-8.2(\mathrm{~m}, 7 \mathrm{H}, \mathrm{Ar}-\mathrm{H} \text { and Furan), } \\
10.7 \text { (brs, } 1 \mathrm{H}, \mathrm{NH})\end{array}$ \\
\hline $4 \mathrm{e}$ & 2-Thionyl & 142 & 3.0 & 7.0 & 65 & 87 & $\begin{array}{l}1.2\left(\mathrm{t}, 3 \mathrm{H}, \mathrm{OCH}_{2}-\mathrm{CH}_{3}\right), \\
2.3\left(\mathrm{~s}, 3 \mathrm{H}, \mathrm{CH}_{3}\right) \\
5.3(\mathrm{~d}, 1 \mathrm{H}, \mathrm{CH}) \\
4.1\left(\mathrm{q}, 2 \mathrm{H}, \mathrm{OCH}_{2}-\mathrm{CH}_{3}\right) \\
7.1-8.5(\mathrm{~m}, 7 \mathrm{H}, \mathrm{Ar}-\mathrm{H} \& \text { Thiophene), } \\
10.8(\mathrm{brs}, 1 \mathrm{H}, \mathrm{NH})\end{array}$ \\
\hline $4 \mathrm{f}$ & Heptyl & 125 & 4.0 & 8.0 & 52 & 73 & $\begin{array}{l}1.2-1.2\left(\mathrm{~m}, 18 \mathrm{H},-\left(\mathrm{CH}_{2}\right)_{6} \mathrm{CH}_{3} \&\right. \\
\left.\mathrm{OCH}_{2}-\mathrm{CH}_{3}\right), \\
2.4\left(\mathrm{~s}, 3 \mathrm{H}, \mathrm{CH}_{3}\right), \\
5.2(\mathrm{~d}, 1 \mathrm{H}, \mathrm{CH}), \\
4.0\left(\mathrm{q}, 2 \mathrm{H}, \mathrm{OCH}_{2}-\mathrm{CH}_{3}\right), \\
7.2-8.4(\mathrm{~m}, 4 \mathrm{H}, \mathrm{Ar}-\mathrm{H}), \\
10.6(\mathrm{brs}, 1 \mathrm{H}, \mathrm{NH})\end{array}$ \\
\hline $4 \mathrm{~g}$ & Nonyl & 132 & 4.0 & 8.0 & 50 & 72 & $\begin{array}{l}1.1-1.2\left(\mathrm{~m}, 22 \mathrm{H},-\left(\mathrm{CH}_{2}\right)_{8} \mathrm{CH}_{3} \quad \&\right. \\
\left.\mathrm{OCH}_{2}-\mathrm{CH}_{3}\right), \\
2.3\left(\mathrm{~s}, 3 \mathrm{H}, \mathrm{CH}_{3}\right), \\
5.3(\mathrm{~d}, 1 \mathrm{H}, \mathrm{CH}), \\
4.1\left(\mathrm{q}, 2 \mathrm{H}, \mathrm{OCH}_{2}-\mathrm{CH}_{3}\right), \\
7.2-8.4(\mathrm{~m}, 4 \mathrm{H}, \mathrm{Ar}-\mathrm{H}), \\
10.6(\mathrm{brs}, 1 \mathrm{H}, \mathrm{NH})\end{array}$ \\
\hline
\end{tabular}

\section{DISCUSSION}

The results obtained clearly show the efficiency of solid supported microwave reaction, over conventional reaction, in terms of reaction time and yield.

The structures of synthesized substituted-2-thioxopyrimidines 4a-g were confirmed from spectral and analytical data (Table 1). IR band at $1220-1232 \mathrm{~cm}^{-1}$ due to thioxo group and the band at $1420-1427 \mathrm{~cm}^{-1}$ due to C-N linkage indicated the formation of 2- thioxo-pyrimidines 4a-g. The IR absorption bands at 3450$3455 \mathrm{~cm}^{-1}$ and $1715-1730 \mathrm{~cm}^{-1}$ showed the presence of secondary amino group and keto group, respectively in the synthesized compounds.

All the aromatic protons appear at $\delta 6.3-8.5$ in ${ }^{1} \mathrm{H}$ NMR analysis. A doublet at $\delta 5.2-5.4$ is observed due to a tertiary hydrogen atom in the pyrimidine ring. Similarly, a broad singlet is observed at $\delta 10.6-10.8$ due to secondary amino hydrogen in synthesized 2-thioxo-pyrimidines 4a-g. 


\section{CONCLUSION}

Solid supported condensation of monosubstitued thioureas la-g with ethyl acetoacetate 2 and arylaldehyde 3 under microwave irradiation gave 1(1,3,4-thiadiazolo)-2-thioxo-Pyrimidines $4 \mathrm{a}$-g with $87 \%$ yield. The reaction completed in 7-8 min compared to $3-4 \mathrm{hr}$ in conventional heating with low yield. Further, the usage of organic solvents has been minimized by adopting solid supported microwave reaction.

\section{ACKNOWLEDGEMENTS}

The author thanks the Department of Chemistry, P.N. Campus for providing laboratory facilities. The characterization and the analytical works were done in the laboratory of Chemistry, University of Delhi, India, as the extension of support in research works.

\section{WORKS CITED}

Banerjee, S., and R. Tyagi. 2009. Synthesis and Characterization of Some Heterocycles. Indian Journal of Chemistry 48B: 882-889.

Banic, Z., M. Grdisa, B. Kofic, and M. Kraji. 1996. Synthetic Use of Thioures. Journal of Medicinal Chemistry 31:23-33.

Bendig, J., J. Liebscher, and B. Riemer. 1994. Bioactivities of Thioxo Derivatives. Tetrahedron Lett. 35: 7009-7015.

Caddick, S. 1995. Use of Alumina in Synthetic Chemistry. Tetrahedron. 51: 10403-10413.

Cole, C., K. T. Douglas, P. N. Edwards, A. Gbaj, and P. Reigan. 2003. Green Synthesis of Pyrroles. Journal of Medicinal Chemistry 46: 207-217.

Damkar, V., and S. K. Mishra. 2006. Thourea Synthesis of Thinoes. Heterocyclic Commun 12:1001-1009.

Daneud, D., M. Evain, and C. Landure. 2002. Synthesis of Oxazoles and Their Bioactiveness, Journal of American Chemical Society. Perkin Tras. 1:741-750.

Deb, C. and S. Kotha. 2008. A Facile Synthesis of Pyrimidines. Indian Journal of Chemistry. 47B: 1120-1127.

Kappe, C., W. Linder, P. Roschger, and G. Uray. 1992. Solvent Free Synthesis of Thiadiazoles. Tetrahedron. 48: 5473-5484. 
Kappe, C. and P. Roscher. 1989. One Pot Preparation of Pyrroles. Journal of Heterocyclic Chemistry 26: 55-62.

Kidwai, M., R. Mohan, S. Saxena, and R. Venkataramanan. 2002. Journal of Chemistry Soc Perkin Trans. 1(16) 1845-1850.

Overman, L.E., M.H. Rabinowitz, and P.A. Renhowe. 1995. Microwave Route for Azo-heterocycles. Journal of American Chemical Society. 117: 26572667.

Verma, R.S. 1999. Solid Supported Synthesis of Heterocycles. Green Chem. 1: 43-663. 